\title{
Negotiating time and space for study: student-parents and familial relationships
}

\author{
Rachel Brooks
}

\section{Published in Sociology}

\begin{abstract}
Historically, university cultures have been described as masculine in orientation, and the ‘ideal learner’ as male, white, middle class and unencumbered by domestic responsibility. Nevertheless, more recent work has highlighted certain spaces within the higher education sector which, it is argued, are more welcoming of female students and those with family commitments. While there may now be more institutional spaces open to student-parents and others with caring responsibilities, we know little about whether similar change has been wrought in the domestic sphere. Drawing on interviews with 68 student-parents, this paper explores the various strategies UK students with dependent children used to find time and space, within the home, to pursue their studies. By comparing these to the strategies used by student-parents at Danish universities, the paper considers the extent to which differences in gender norms and state policy with respect to both higher education and childcare affect dayto-day familial practices.
\end{abstract}




\section{Introduction}

Historically, university cultures have been described as masculine in orientation, in which women face barriers to both access and success and are excluded from positions of power (Morley, 1999). Moreover, the ‘ideal learner’ has frequently been constructed as male, white, middle class and ‘unencumbered by domestic responsibility' (Leathwood and O’Connell, 2003:599). Nevertheless, more recent work has highlighted certain spaces within the UK higher education (HE) sector which, it is argued, are more welcoming of female students and those with family commitments (Reay et al., 2010). For example, newer higher education institutions (HEIs), particularly those that gained university status since 1992, have been shown to be attractive to many female students with caring responsibilities - as a result of their perceived diversity when compared to more traditional universities and their construction, by some, as working class spaces (Archer et al., 2003). Quinn (2003:453) has gone as far as to suggest that women students often perceive the university as a refuge from various external threats. She maintains that, for the women in her study, it represented a place of safety from various forms of physical, emotional and intellectual threat which they encountered in other locations, a place in which the 'vulnerable self might have some chance to emerge'.

While there may now be more institutional spaces open to student-parents and others with caring responsibilities, we know relatively little about whether similar change has been wrought in the domestic sphere. The few studies that have been conducted in this area have suggested that female student-parents continue to experience considerable pressure to downplay their 'student' identity while at home and to retain their role as main care-giver irrespective of the demands of their university course. On the basis of her work in the US, 
Lynch (2008:595) argues that student-mothers engage in complex 'identity practices', through which they 'manage their conduct in interaction with dominant cultural conceptions about what it means to be both a "good mother" and a "good student”'. She contends that as the symbolic nature of both roles is often in conflict, student-mothers adopt strategies to minimise such conflict. This involves downplaying their maternal role when they are at university and concealing their student role when they are outside the university. While such identity practices may help student-mothers feel they are conforming to dominant expectations of the diligent student, who is unswervingly committed to her studies, and the attentive mother, whose time, energy and money is devoted to raising her children, they result, Lynch (2008) argues, in significant stress. Within a UK context, Quinn (2003) has also argued that student-mothers often try to separate spaces of study from those of home. However, amongst her respondents, this was not through a desire to maintain two distinct identities; instead, they were concerned to protect the 'safe space' of university from the encroachments of home.

Extant research has certainly suggested that the home environments of student-parents are not always supportive of and conducive to study. Indeed, Archer et al. (2003) have documented familial resistance to student-mothers based on the perceived 'irresponsibility' of engaging in study while also being a mother, while Osborne et al. (2004) maintain that, for many women, studying is an 'extra' to be fitted in once childcare duties have been completed. Osborne et al. suggest that men also face gendered expectations that affect decisions about HE, with those who see themselves as 'breadwinners' being reluctant to opt for full-time programmes of study. In explaining these patterns, scholars have tended to draw on dominant social constructions of the roles of men and women (Alsop et al., 2008). However, there has been little work which has explored the way in which familial negotiations, with respect to 
studying, are conducted in countries with different understandings of male and female roles. We know little, therefore, about whether societal differences in gender relations result in different experiences on the part of student-parents. To start to redress this gap, this article draws on data from two European countries with different gender norms - the UK and Denmark - to explore the various strategies that HE students with dependent children use to find time and space to pursue their studies. Denmark, like its Scandinavian neighbours, has lower levels of gender inequality than the UK (Crompton et al., 2007) and has had an 'adult worker' model of gender relations in place for a considerably longer period of time (Lewis, 2001). In this way, the article makes the most of what Hearn and Pringle (2006:369) term the ‘social laboratory of policy and...societal development, including gender relations’ that Europe represents.

Across Europe, access to higher education has been a significant political struggle, particularly for women and those from lower socio-economic groups. While important gains have been made in terms of gender ${ }^{\mathrm{i}}$ (indeed, women now outnumber men within HE in both the UK and Denmark), differences remain: women are under-represented on many mathematics, science and engineering courses, and at doctoral level (Leathwood and Read, 2009). With respect to socio-economic status, the differences are even more marked. In England, for example, despite over a decade of initiatives to 'widen participation', students from working class backgrounds are still much less likely to enter university than their middle class counterparts and be found in prestigious institutions (National Equality Panel, 2010). Both gender and social class continue to affect the experiences of those entering HE, and constitute an important focus of this article. It has been argued by some that inequalities by both these variables are likely to be exacerbated by recent policy developments in England. Concern has been expressed that the significantly higher HE tuition fees, payable 
from September 2012, will deter those from less privileged backgrounds, while the Coalition government's reassertion of a male breadwinner model of gender relations (Toynbee, 2012) may have the effect of discouraging women's participation in the labour market and, perhaps also, in education and training.

\section{Research methods}

Research was carried out in the UK and Denmark during the 2010-11 academic year. Within the UK, fieldwork was conducted in ‘Older University’ and 'Newer University’. Older University is a high status institution, which usually ranks highly in international league tables. It draws its student body from across the UK, as well as internationally, and tends to have a relatively small number of 'non-traditional' students. In contrast, 'Newer University' is a much less prestigious institution, which does not rank highly in international league tables and has a relatively high proportion of non-traditional students. Within Denmark, research was also conducted at one 'Older' and one 'Newer' university. Here, however, differences between institutions are less marked - particularly in terms of status. 'Older University' is one of the biggest universities in Denmark and offers a wide range of undergraduate and postgraduate programmes. 'Newer University’ gained university status relatively recently and offers mainly applied and professionally-oriented undergraduate programmes. In each university, semi-structured interviews were conducted with at least two staff members responsible for student welfare and at least 13 student-parents $^{\mathrm{ii}}$ (see Table 1).

Insert Table 1 
Table 1 highlights some important differences between the respondents at the four institutions, which have some bearing on the arguments that are developed later in the paper. In common with universities generally in both countries, none of the four institutions in the sample collected data on student-parents. It is therefore not possible to say with any certainty whether the characteristics evident in Table 1 are an accurate reflection of the wider population of student-parents at each university. Nevertheless, previous research within the UK has indicated that student-parents are better represented amongst postgraduates than undergraduates $^{\mathrm{iii}}$ (NUS, 2009), while the staff interviews suggested that the gender profiles and the split between part-time and full-time and between undergraduate and postgraduate may be broadly representative of the student-parent body at the research sites. As will be discussed below, there were some important differences between the postgraduates (who were enrolled on both masters and doctoral programmes) and their undergraduate counterparts. For example, the former typically had fewer timetabled classes and thus much more flexibility about when and where they studied. However, there were also important commonalities across both groups: the patterns described below were evident among both undergraduates and postgraduates in the two HEIs where both were interviewed (UK Newer and Danish Older). Across the sample, respondents were enrolled on a very wide range of courses. Although this included many traditional academic subjects, a majority of respondents were following vocational courses. Again, however, there was variation between the four institutions: relatively few of the UK Older students were following vocational courses, while almost all of those at Danish Newer were enrolled in such programmes. These differences relate to the different missions and histories of the universities, outlined above.

Across this dataset, three distinct models of familial negotiations emerged, as student-parents sought to combine study with their responsibilities to their children and, for those who were 
married or co-habiting, to their partner. In general, these were closely related to the particular university that the student was attending. In the following sections of the article, these three models (UK Newer University, UK Older University and Danish Older and Newer Universities) are described in some detail. The paper then explores some of the likely reasons for the evident national and institutional variations.

\section{Differing models of familial negotiation}

\section{UK Newer University}

In many ways, the patterns evident in the narratives of respondents from 'UK Newer University’ reflect dominant themes in the extant literature on mature students in general, and student-parents in particular. As Table 1 demonstrates, the vast majority of the respondents from this institution were women and, on the whole, their age profile was rather older than interviewees at the other three universities. When describing how they came to choose to study at UK Newer, many spoke of the significant geographical constraints on their choices: very few had even considered the possibility of moving house to pursue a degree course, and many had chosen UK Newer primarily because it was the local university. Specific familial commitments such as taking children to school could thus be maintained. As other scholars have suggested, the notion of 'choice biographies' (du Bois Reymond, 1998) which has often been deployed to conceptualise the decision-making processes of 'traditional-age' students, seems to offer little analytical purchase on the experiences of older students with domestic responsibilities (Marandet and Wainwright, 2010). 
Although many of the student-parents at UK Newer were living with a partner, the vast majority described how, throughout their studies, they had continued to do all or almost all of the childcare within the family. Abigail ${ }^{\text {iv }}$ was typical of many in claiming that:

In terms of actual childcare responsibility, I don't think doing a PhD has had any impact....I do the majority of the day-to-day tasks that need to get done, the packing lunches, the getting [children] washed and dressed.

Again, these findings are broadly in line with those of previous UK-based research on students with caring responsibilities. Moss (2004:290) has described the effort exerted by her respondents to find any time at all for studying within busy family lives and the 'intense activity and negotiations’ required to achieve ‘some control of time and space for themselves'.

The UK Newer students drew on a diverse range of childcare strategies as part of their balancing acts, often relying on informal arrangements with friends, parents and/or older children:

Luckily, this term, [older daughter] is only at uni two days a week...so the days I'm at uni she can pick up [younger daughter].....And if anything came up really bad, my dad is retired so he'll...have her. (Beatrice, undergraduate, single parent ${ }^{\mathrm{v}}$ )

Formal daycare provision (such as nurseries) was used in very few cases by these students. In large part, this was because their children were old enough to attend school. A more common strategy was for student-parents to curtail their study hours significantly, to fit within the 
school day, so that they were available to spend time with their children from mid-afternoon onwards.

The spaces in which UK Newer students chose to study were influenced by similar concerns. The majority preferred to study at home rather than at university as this enabled them to: spend more time with their children; be closer to their children's schools; get on with some domestic tasks (such as laundry) at the same time; and minimise travel costs. Amongst this group of respondents there was thus little evidence of a desire to keep university and domestic life separate, in the ways discussed by Quinn (2003) and outlined previously. Although practical considerations (and, in particular, the need to be around after-school to look after their children) would have made it difficult for these student-parents to protect their university lives from the 'encroachments' of home, they expressed little frustration with this; indeed, most had an active desire to be around for their children and no discernible wish to establish strong boundaries between the two. Thus, for many of the UK Newer respondents, their identity as a parent seemed considerably stronger than their identity as a student. Over a quarter were studying on a part-time basis and almost all viewed study as something to be fitted around existing childcare commitments. Daisy (postgraduate) was typical of many in claiming that, once she had finished her university day, 'I have to go home to my other job, my real job of being a mum and, you know, a wife and family’.

Although none of the respondents regretted their decision to embark upon a degree, a large number spoke of the guilt that they had felt at some point in their studies. Moss (2004:294) has suggested that, for some women, finding time and space for study 'is akin to finding leisure time, in particular when it was conceived as time for self or selfish time'. Similar assumptions appeared to underpin the narratives of many of the UK Newer students: 
It makes me feel quite guilty really a lot of the time because I've got to spend so much time on [academic] work and I feel like it’s not fair on her. (Emily, undergraduate)

Overall, the attitudes and experiences of the UK Newer students were broadly in line with what previous work on student-parents has revealed: the majority were women who, although committed to their studies, prioritised their responsibilities to their children and identified primarily as a parent rather than as a student. Many felt considerable guilt at pursuing a degree and devoted enormous energy to juggling study and childcare, to ensure that family routines were disrupted as little as possible. For these students, there was a notable absence of familial negotiation: domestic responsibilities had been altered little as a result of study. In contrast to some studies, however, there was little evidence of respondents seeking to protect their university lives from the encroachments of home, nor was there any evidence of maternal identities being downplayed or concealed at university.

\section{UK Older University}

The second UK university in the sample - UK Older - showed marked differences from both UK Newer and other institutions which are discussed in the wider literature. Firstly, the HE choices of almost all the UK Older respondents showed no signs of being geographically constrained. Indeed, as Table 1 indicates, many were overseas students and had moved considerable distances (with their families) to pursue their degree course. Secondly, the sample was split equally between male and female students. As discussed above, it is not possible to tell with any certainty whether the achieved sample is representative of the broader population of student-parents within each university. Nevertheless, evidence from 
staff at UK Older suggested that men were well-represented among the body of studentparents.

Unlike UK Newer, where there were many broad similarities across the sample, at UK Older, the experiences of male and female student-parents varied considerably. Typically, the male student-parents had a female partner who took full responsibility for childcare. As a result, they were able to immerse themselves completely in their academic studies, as Philip described:

What's been exciting for me is you are not only able to interact with people within your programme, as it were, but beyond: you have so many seminars you can go to, you have talks you can go to, so many avenues when you can actually interact and hear people, hear what they're doing, share what you're doing.

Although, in most cases, the female partner was not in paid employment, there were examples within the sample of families in which the woman worked full-time and also did all of the childcare, to support her partner:

Luckily my wife supports me quite a lot...she finished her $\mathrm{PhD}$ before me, so she's got a normal job now.....so that means she doesn’t have to work long hours, or she has a more regular day than I do. So she starts at 8 and can finish [at] 5, 6. And my daughter goes to nursery now, so she brings her there, takes her back, while I sometimes have to work at night. (Paul) 
As a result of these domestic arrangements, very few of the men in the sample thought that having children had any negative impact on their academic studies; in contrast, many talked about the 'healthy discipline’ having a family imposed, providing a strong incentive to work in a focussed manner during the day, and to spend the evenings engaged in other activities. Very few spoke of any competing priorities on their time: some did discuss the obligation they felt to spend some time with their family in the evening, but this was seen largely in positive terms.

In contrast to the way in which study by a female student-parent is often assumed to be akin to a leisure activity (discussed above), the male student-parents at UK Older (and, it seems, their families) frequently equated study with full-time paid work. Indeed, when asked about the domestic arrangements within his family, Stephen explained 'because I am working, my wife is doing most of the housework'. This attitude was also reflected in the places in which the male student-parents chose to study. While the majority of respondents at UK Newer spoke of the advantages of working at home, the student-fathers at Older UK tended to prefer to work away from the home, in university spaces. Jim saw the two spaces in considerable tension: ‘[home is] just not compatible with intellectual engagement really....they're just very conflicting realities'. Similarly, Stephen explained that 'I made it quite clear [to my family] that I will do all my work in the department, and I will return home only when I am free to spend some quality time with my family'. Although, in some cases, this physical separation was prompted by the distractions of having a partner and small children at home, it does underline the wider choices available to the male UK Older student-parents when compared with their female counterparts at UK Newer. Indeed, this seems to be a good illustration of the broader point Miller (2011b:21) has made about the inequalities inherent in contemporary parenting more generally: 'As women continue to be positioned as primary carers this affords 
men other choices and opportunities in a context where motherhood can be viewed as a societal duty and fatherhood as personal and elective'.

While the female student-parents at UK Older did not have the same domestic arrangements as their male peers (i.e. a stay-at-home partner who took primary responsibility for the childcare), neither did they follow the pattern of the UK Newer student-parents who tended to squeeze studying around their well-established childcare commitments. Instead, the majority were able to spend most of the working day on their studies as their children were in full-time childcare or school and after-school provision. In some cases, the childcare was funded by a scholarship the student had received; in others, it was paid for by their husband's income. However, while they were able to work full-time on their degree programme, unlike their male counterparts, they tended to assume responsibility for dropping off children at nursery or school and picking them up again at the end of the day. Moreover, many spoke about feelings of guilt in relation to their children - sentiments which were notably absent from the narratives of the student-fathers. The spaces in which they chose to study were also much more likely to be influenced by child-related factors than in the male sample. In some cases this was simply because their homes were quieter and thus more conducive to study, as their children were at nursery or at school. However, in other cases, respondents wanted to be in close physical proximity to their children, as Lily explained:

I've been studying in the maths department [despite studying for a PhD in French] because it's just next to the nursery.

In general, the experiences of student-parents at UK Older provides support for Baxter and Britten's (2001) contention that while female partners of male students adjust their lives to 
take account of their partner's status as a student, considerably less adjustment, if any, is made by male partners of female students.

Nevertheless, the ‘student identity’ of both male and female student-parents seemed considerably stronger than that of their counterparts at UK Newer. In part, this can be explained by: their status as full-time, rather than part-time, students; the way in which study was treated - by both men and women - as similar to a full-time job, rather than an activity to be squeezed into the spaces not filled by other commitments; and perhaps also the prestige associated with studying at a high status institution. However, it also seems likely that the wider institutional culture had an impact on learner identities. Reay et al. (2010:120) have shown how 'the rewards and recognition of being a university student are powerfully differentiated across the higher education field' and highlighted important variation in the extent to which identification as a 'university student' becomes an individual's main source of identity. In institutions where students are attempting to juggle multiple commitments, Reay et al. argue that being a university student is much less likely to be taken on as a primary identity.

\section{Danish Newer and Older Universities}

In contrast to the differences between the UK institutions, strong similarities were evident between students at the two Danish universities in the sample. As Table 1 demonstrates, although the proportion of male and female students differed between the two Danish institutions, the higher status institution did not seem to have attracted a larger number of male student-parents, as was the case in the UK. Moreover, across both Danish Newer and Danish Older, many respondents reported that their partner was either also a student, or had 
been one recently. In the narratives of these students, there was a strong discourse of 'turntaking' in relation to study, which was notably absent from their UK counterparts; HE study was thus understood as an activity open equally to both fathers and mothers.

The majority of the Danish interviewees, across both sites, either used state-provided daycare or had children of school-age. Very few reported any problems with finding or affording childcare, even those from families in which the sole source of income was their student grant. Denmark devotes more of its GDP to the provision of childcare than any other member of the OECD and, as a result, is able to offer nursery places to students and others on low incomes at very low cost (Bonoli et al., 2010). Consequently, few respondents had to rely on the ad hoc arrangements evident at UK Newer, and study did not have to be 'squeezed' into the gaps left between other activities. The option to study on a genuinely full-time basis was available to most of the male and female student-parents in the Danish sample. Nevertheless, a considerable number of respondents - both men and women - described how one of the most significant benefits of being a student-parent (as opposed to a full-time worker) was the flexibility it afforded to vary one's hours of work, and thus spend more time with one's children.

The flexibility of being a PhD student, I would say it's a privilege in that respect because I can go home early, I can be part of her [daughter’s] life. (Christian, Danish Older, postgraduate)

When I was working, I was so stressed....[now, as a student] I have more time and I give more time to them [children]. (Karen, Danish Newer, undergraduate) 
Some respondents described how they had even planned their pregnancy so that their degree course coincided with the first few years of their child's life. Thus, across the Danish sample, there were few examples of the strong ‘student identity' evident among the male studentparents at UK Older University. However, there were also fewer examples of the strong parental identity which was dominant at UK Newer University. There were also fewer differences by gender: the majority of both the males and females in the Danish sample appeared to have reasonably balanced identities, in which both their identity as a student and as a parent seemed to be attributed equal importance.

As a result of respondents' reliance on formal daycare provision, common across both Danish institutions, daytime childcare rarely had to be negotiated between partners. Nevertheless, with respect to care of children at the start and end of the day, there were many more examples of equal sharing than was evident in the UK sample. Although there were a number of exceptions, a majority of interviewees believed that both childcare and domestic chores should be shared equally between parents - even if one was in paid employment and the other was a student:

My girlfriend does most of the cooking and shopping but I do most of the laundry and most of the cleaning in the flat. It is more or less the same as before [I started studying]. (Frederik, Danish Newer, undergraduate)

This appeared to be the case irrespective of whether it was the mother or the father who was the student-parent. 
The Danish students also differed from their UK counterparts in relation to the places in which they studied. As noted above, the female student-parents at UK Newer and, to a lesser extent, UK Older, generally preferred to study at home, or in other spaces that were in close proximity to their children. In contrast, the male student-parents (at UK Older) tended to make a clear physical separation between 'home’ and ‘study’ spaces. Within both Danish Newer and Danish Older, the picture was much more mixed. No clear patterns were evident by gender, or with respect to the two institutions. Instead, the main determining factors appeared to be whether respondents were enrolled on an undergraduate or postgraduate course, and the distance they lived away from the university. Postgraduates were more likely than undergraduates to have their own offices, and so tended to prefer working in them as they were quieter than the communal spaces they had inhabited as undergraduates. Those who lived further away from the university tended to spend more time studying at home than their peers who lived closer.

Finally, very few Danish respondents appeared to feel any guilt about combining studying with bringing up a young child - which, as noted above, was a common theme in the interviews with many student-mothers (although not student-fathers) at both the UK universities. Indeed, many spoke about the flexibility which study afforded - to care for an ill child, or just spend more time with them generally - which would not have been available if they had been in full-time employment. Indeed, the comparison that was frequently drawn in many of the Danish narratives was between studying and full-time work. The assumption made by the student-parents was that if they were not studying, they would be working - and, thus, most believed that their children benefitted from the arrangement as they saw more of them than would otherwise be the case. In contrast, the comparison made by the women at UK Newer and, to a lesser extent, UK Older, was rather different. As they compared studying 
with full-time childcare rather than full-time paid employment, they believed that their children were seeing less of them than they otherwise would have done, and so may be being disadvantaged by this arrangement.

\section{Discussion}

\section{Identity practices}

The preceding sections of this article have emphasised important differences in the extent to which respondents identified as a student and/or a parent. However, it is also important to recognise that, across all four sites, there was little evidence of any of the student-parents engaging in the complex 'identity practices’ described by Lynch (2008). Indeed, only two interviewees talked of consciously ‘downplaying’ their student identity at home; almost all appeared happy to talk about their studies with their partner and/or their children. Despite the guilt discussed above, many respondents claimed that they had become a 'better mother' as a result of their study, often because they believed they were offering a positive role model to their children. Thus, being a student per se was not seen as necessarily in tension with a 'good parent' role. Similarly, few respondents had taken active steps to restrict the amount they talked about their children whist they were at university. Nevertheless, this is not to say that the two roles (of student and parent) always fitted well together, or that there were no tensions between the two. Here, there were important differences by both nation and university attended.

Feminist scholarship, within the sociology of education, has witnessed a distinct shift over recent decades from a concern with women's education (e.g. Deem, 1984) to a broader 
theoretical focus on the formation of gender identities (e.g. Mac an Ghaill, 1994; Reay, 2001; Skelton and Francis, 2009). This body of work has demonstrated how gender is both changeable and permeable. Moreover, it has argued that there is no single form of masculinity or femininity in educational institutions but, instead, 'many competing and contradictory forms, each of which is contingent on the conditions of gender regulation' (Dillabough, 2006:23). Contemporary research on parenting has adopted a similar theoretical position (Dermott, 2008; Miller 2011a). In her work on fathering, Miller (2011a:1096) contends that the discourses which frame men's transition to fatherhood 'are rooted in powerful social, cultural and historical constructions of hegemonic masculinities (the breadwinner as economic provider and protector), as well as more recent constructions of "involved fathering” and the "good father"' which emphasise intimacy, care and a commitment to gender equality. These latter constructions, she suggests, have emerged as a result of the more general recognition of masculinity as plural and diverse (Connell, 1995). In line with such arguments, the previous sections of this article have illustrated some of the differences in the ways in which identities of both parent and student were played out between countries and, in the case of the UK, between institutions. The reasons for these variations will now be explored.

\section{National differences}

While some gender scholars have argued that, even in countries with strong discourses of equality and policies to facilitate shared caring, men are still more able than women to determine the terms for their engagement and participation (Miller, 2011a), others have emphasised important differences between nation-states in men's involvement in childcare (Almqvist, 2008). Such differences articulate with feminist scholarship, which has argued 
that the state, national policy and economics all play an important role in shaping girls' and women's education (Dillabough, 2006). Theorists of masculinity have proffered similar arguments, contending that 'masculinity as a personal practice cannot be isolated from its institutional context....Three institutions - the state, the workplace/labour market and the family - are of particular importance in the contemporary organisation of gender' (Connell, 2006:104). In line with such arguments, the contrasting models of familial negotiation, outlined in this paper, do indicate significant variation by nation, and thus suggest that both the state and national policy have considerable bearing on the shape of student-parents' lives.

As the data reported above have suggested, there were significant differences between the UK and Denmark with respect to the distribution of childcare and domestic chores within the family. The sharing of such tasks, irrespective of which partner was the student, was much more common in the Danish sample than the British sample. Amongst Danish respondents, there was also a strong commitment to ‘turn-taking' with respect to study, and a belief that both partners were entitled to study for a degree at some point in their lives. These differences are consonant with the wider literature on gender relations in Europe. Although Crompton et al. (2007) have noted that attachment to the male breadwinner model of gender relations has not totally disappeared, even in countries with the most progressive politics, in general, countries with social democratic welfare regimes, such as Denmark, have lower levels of gender inequality and men are typically more involved in family life than in nations with neo-liberal welfare regimes, such as the UK (ibid.).

The greater involvement of fathers in the lives of their children within Denmark and other social democratic welfare regimes is often seen as a direct result of specific gender-related policies, including: relatively good daycare provision; generous parental and paternal leave; 
and significant attempts to develop a home-work reconciliation policy (Hearn and Pringle, 2006). However, such countries have also had a long history of women’s full-time employment, which has militated against the establishment of a male breadwinner state. Thus, as Miller (2011b:22) contends, 'redefinitions and reimaginings of contemporary fatherhood have been differently interpreted and enabled, or at least recognised, in policies and practices across different European countries' - with a discourse of 'shared parenting' and more child-centred masculinities evident in the Nordic countries, while an emphasis on the economic obligations of fathers has remained pervasive in the UK.

Dominant discourses about the role of fathers and mothers in society also help to explain why feelings of guilt in relation to how they spent their time were common amongst many of the UK student-mothers but rarely articulated by their Danish counterparts. Over recent decades, English education policy has often emphasised the role of parents as 'home educators' and privileged a particular middle-class version of parenting (Gewirtz, 2001). This has much in common with 'intensive mothering', which:

requires the mother to take on complete responsibility for all aspects of children's cognitive, social, emotional and physical development. It requires a centring of children and their needs in family life, accompanied by a considerable degree of maternal self-sacrifice. (Braun et al., 2008:545.)

In contrast, in social democratic countries like Denmark, professional care is seen as beneficial for children and European surveys have consistently shown that Danes are more likely than any other national group to ‘approve’ of women with young children engaging in paid employment (Saraceno, 2011). Such attitudes are closely related to the provision of 
childcare. Significant national investment has ensured that affordable daycare is available throughout Denmark. As a consequence, it has the highest percentage of 0-3 year-olds in formal daycare of any OECD country (Bonoli and Reber, 2010). Indeed, 62 per cent of under-threes attend formal daycare in Denmark, compared with only 26 per cent in the UK (Saraceno, 2011). It is likely that such differing national norms with respect to childcare have a significant bearing on the extent to which student-mothers feel a sense of guilt at not 'being around' for their children throughout the day.

\section{Institutional differences}

A further national difference relates to the degree of inter-institutional variation evident within each country. As discussed previously, the experiences reported by students at both Danish universities were very similar. In contrast, there were considerable differences between the narratives of the UK Newer respondents and those of their counterparts at UK Older - differences which have not been identified in previous research on student-parents. This variation can be explained, at least partially, by the different ways in which the HE sectors in the two countries are structured. The UK HE sector is much more market-driven than its Danish counterpart; this system encourages universities to develop potentially very diverse policies and practices that are perceived to fit their particular market segment (Brooks, 2011). It is also much more internally differentiated than the Danish HE sector, comprising a number of very high status institutions - three in the top ten, internationally - as well as many of much lower status. In contrast, none of Denmark's universities are in the top 100, internationally. Research has consistently shown how these variations in institutional status in the UK are mirrored in the social characteristics of the students who attend them (Reay et al., 2010). 
The data from the UK student-parents suggests that the variation in status between the two institutions may help to explain a number of differences between the narratives of respondents at UK Newer and UK Older. Firstly, as noted above, there were many more men in the UK Older sample than the UK Newer sample, and interviews with staff suggested that this was a fair representation of the wider student-parent population at both institutions. Osborne et al. (2004) have argued that many men are reluctant to embark on a course of fulltime study because they believe it compromises their identity as main income provider. However, it may be the case that the status associated with attending a prestigious university with an international profile helps to mitigate the perceived loss of status associated with being a student. Moreover, several respondents hoped that having a degree from UK Older would significantly strengthen their labour market position, and thus be of eventual economic benefit to their family. It is possible that studying at a lower status university does not offer the same status rewards to men, and so is less likely to be considered as a serious option. If studying at a high status HEI is seen as an acceptable substitute for full-time work, then this may explain why so many of the partners of student-fathers at UK Older cared for their children on a full-time basis rather than engaging in paid employment - effectively replicating male-breadwinner and female-caregiver roles.

Secondly, the status differences may also help to explain the differential financial resources upon which students were able to draw and, thus, differences in the type of childcare that was available to them. Previous research has shown that students from affluent families tend to be over-represented within prestigious universities, while those from poorer backgrounds are more likely to attend less prestigious institutions (Archer et al., 2003) - despite a number of recent policy initiatives which have aimed, specifically, to increase the proportion of 'non- 
traditional' students at elite universities. Moreover, at the postgraduate level, a greater proportion of students at higher status universities than at lower status institutions tend to be funded through scholarships (Corbyn, 2009). Data from the current project certainly suggests that scholarships were an important source of income for student-parents at UK Older, and often made possible full-time childcare. No respondent at UK Newer described a similar type of support.

Finally, the extent to which the respondents at UK Older and UK Newer developed a strong student identity may also relate to status differentials between the two universities. In their research on working class students at four UK universities, Reay et al. (2010) argue that there are significant differences in institutional habituses, which have an important bearing on the type of learner identity taken on by students. Within the elite institution in their sample, being a university student invariably became the individual's main source of identity. In contrast, at the lower status university in their sample, 'students have a number of competing identities.....They are jostling work and family commitments with doing a degree and often the first two overwhelm and take precedence over studying' (p.115). Very similar differences were apparent between the students at UK Older and UK Newer although, at UK Older, they were to some extent mediated by gender.

In many ways, these findings reflect the 'paradox of contemporary femininities' outlined by Reay (2001). She argues that, while we have much to celebrate in the achievements of middle class girls and women,

The situation for working class girls and women remains less positive. They are often marginalized and excluded from the more positive shifts in constructions of 
femininity experienced by their middle class peers....Transformation in the way femininity is lived for girls and women continue to be mediated by the intransigence of class. (p.163)

While there was not a straightforward correlation between social class and university attended amongst the respondents at the UK universities, in general, those at UK Older did have considerably more economic capital to draw upon than their counterparts at UK Newer. This could be used either to purchase childcare or enable one parent to remain at home to provide childcare which, in turn, freed up more time for student-parents to devote themselves to their studies and develop a more student-oriented identity.

\section{Conclusion}

This article has argued that, for most of the student-parents interviewed as part of this project, taking on an identity as a student was not seen as necessarily in tension with that of a parent; indeed, many were keen to share their university lives with their partner and/or children. There was thus little evidence of the complex identity practices described by Lynch (2008). Nevertheless, this is not to say that the two roles were always easily combined, or that experiences were identical across the sample. The preceding discussion has emphasised, firstly, the considerable national variation in the way in which student-parents and their families negotiated time and place for study. Gender differences were significantly more pronounced among the UK respondents than among their Danish peers. Secondly, it has highlighted institutional variation. While the experiences of students at both Danish universities were very similar, those of their UK counterparts differed markedly: the extent to which students were able to and/or inclined to take on an all-encompassing student identity 
was very different in UK Newer and UK Older. The article has suggested that such variations are intimately related to the hierarchical nature of the UK HE sector, with status differences between institutions affecting the type of student who is recruited, the financial resources to which they have access - and, ultimately, the way in which time and space for study is negotiated within familial relationships.

\section{References}

Almqvist, A.-L. (2008) Why most Swedish fathers and few French fathers use paid parental leave: an exploratory study of parents, Fathering, 6, 2, 192-200.

Alsop, R., Gonzalez-Arnal, S. and Kilkey, M. (2008) The widening participation agenda: the marginal place of care, Gender and Education, 20, 6, 623-37.

Archer, L., Hutchings, M. and Ross, A. (2003) Higher Education and Social Class London, Routledge.

Bonoli, G. and Reber, F. (2010) The political economy of childcare in OECD countries: explaining cross-national variation in spending and coverage rates, European Journal of Political Research, 49, 97-118.

Braun, A., Vincent, C. and Ball, S. (2008) 'I’m so much more myself now, coming back to work' - working class mothers, paid work and childcare, Journal of Education Policy, 23, 5, 533-548. 
Brooks, R. (2011) Student-parents and higher education: a cross-national comparison, Journal of Education Policy (Advance online publication).

Connell, R.W. (1995) Masculinities Cambridge, Polity.

Connell, R.W. (2006) The big picture: masculinities in recent world history, in: Arnot, M. and Mac an Ghaill (eds) The RoutledgeFalmer Reader in Gender and Education London, Routledge.

Corbyn, Z. (2009) ESRC puts doctoral training in few hands, Times Higher Education, 21/5/09.

Crompton, R., Lewis, S. and Lyonette, C. (2007) Continuities, Change and Transformations, in: Crompton, R., Lewis, S. and Lyonette, C. (eds) Women, Men, Work and Family in Europe, Basingstoke, Palgrave.

Deem, R. (ed.) (1984) Schooling for Women's Work London, Routledge and Kegan Paul.

Dermott, E. (2008) Intimate Fatherhood London, Routledge.

Dillabough, J. (2006) Gender theory and research in education: modernist traditions and emerging contemporary themes, in: Arnot, M. and Mac an Ghaill, M. (eds) The RoutledgeFalmer Reader in Gender and Education, Routledge, London. 
Du Bois Reymond, M. (1998) I don’t want to commit myself yet: young people’s life concepts, Journal of Youth Studies, 1, 1, 63-79.

Gerwirtz, S. (2001) Cloning the Blairs: New Labour's programme for the re-socialization of working class parents, Journal of Education Policy, 16, 4, 365-378.

Hearn, J. and Pringle, K. (2006) Men, masculinities and children: some European perspectives, Critical Social Policy, 26, 2, 365-389.

Leathwood, C. and O’Connell (2003) 'It's a struggle': the construction of the 'new student' in higher education, Journal of Education Policy, 18, 6, 597-615.

Leathwood, C. and Read, B. (2009) Gender and the changing face of higher education: a feminized future? Maidenhead, Open University Press.

Lewis, J. (2001) The decline of the male breadwinner model: implications for work and care, Social Politics, 8, 2, 152-169.

Lynch, K. (2008) Gender roles and the American academe: a case study of graduate student mothers, Gender and Education, 20, 6, 585-605.

Mac an Ghaill, M. (1994) The Making of Men Buckingham, Open University Press. 
Marandet, E. and Wainwright, E. (2010) Invisible experiences: understanding the choices and needs of university students with dependent children, British Educational Research Journal, 36, 5, 787-805.

Miller, T. (2011a) Falling back into gender? Men’s narratives and practices around first-time fatherhood, Sociology, 45, 6, 1094-1109.

Miller, T. (2011b) Making Sense of Fatherhood. Gender, Caring and Work Cambridge, Cambridge University Press.

Morley, L. (1999) Organising Feminisms: the micropolitics of the academy London, Macmillan.

Moss, D. (2004) Creating Space for Learning: conceptualising women and higher education through time and space, Gender and Education, 16, 3, 283-302.

National Equality Panel (2010) An anatomy of economic equality in the UK London, Government Equality Office.

National Union of Students (2009) Meet the Parents. The experiences of students with children in further and higher education London, NUS.

Osborne, M., Marks, A. and Turner, E. (2004) Becoming a mature student: how adult applicants weight the advantages and disadvantages of higher education, Higher Education, 48, 291-315. 
Quinn, J. (2003) The dynamics of the protected space: spatial concepts and women students, British Journal of Sociology of Education, 24, 4, 449-461.

Reay, D. (2001) The paradox of contemporary femininities in education, in: Francis, B. and Skelton, C. (eds) Investigating Gender. Contemporary Perspectives in Education Buckingham, Open University Press.

Reay, D., Crozier, G. and Clayton, J. (2010) 'Fitting in’ or ‘standing out': working class students in UK higher education, British Educational Research Journal, 36, 1, 107-124.

Saraceno, C. (2011) Childcare needs and childcare policies: a multidimensional issue, Current Sociology, 59, 1, 78-96.

Skelton, C. and Francis, B. (2009) Feminism and 'the Schooling Scandal' London, Routledge.

Toynbee, P. (2012) Calm Down Dears? Why it's a bad time to be a British woman, The Guardian, $8^{\text {th }}$ March, p.1.

\section{Acknowledgements}

I would like to thank: Sarah Robinson and Victoria Young who conducted many of the interviews; the Nuffield Foundation for funding the research upon which this paper is based; and Heather Mendick and the anonymous referees for their helpful comments. Most of all, I 
would like to thank all the student-parents who found time in their busy lives to take part in the project.

\section{Biography}

Rachel Brooks is Professor of Sociology at the University of Surrey and co-editor of Sociological Research Online. Her research interests focus largely on post-compulsory education, and her most recent books are Student Mobilities, Migration and the Internationalization of Higher Education (Palgrave, 2011, with Johanna Waters) and Changing Spaces of Education: New Perspectives on the Nature of Learning (Routledge, 2012, with Alison Fuller and Johanna Waters). 
Table 1: Characteristics of the respondents at each of the four institutions (N)

\begin{tabular}{|c|c|c|c|c|}
\hline & UK Newer & UK Older & Danish Newer & Danish Older \\
\hline Female & 17 & 10 & 8 & 14 \\
\hline Male & 2 & 10 & 5 & 2 \\
\hline Age under 30 & 4 & 6 & 4 & 1 \\
\hline Age 30-39 & 6 & 9 & 6 & 13 \\
\hline Age $40+$ & 9 & 5 & 3 & 2 \\
\hline Undergraduate & 7 & 0 & 13 & 2 \\
\hline Postgraduate & 12 & 20 & 0 & 14 \\
\hline Home & 17 & 8 & 12 & 14 \\
\hline Overseas & 2 & 12 & 1 & 2 \\
\hline Full-time & 14 & 19 & 13 & 16 \\
\hline Part-time & 5 & 1 & 0 & 0 \\
\hline Co-habiting/ & 13 & 20 & 13 & 14 \\
\hline \multicolumn{5}{|l|}{ married } \\
\hline Single parent & 6 & 0 & 0 & 2 \\
\hline One child & 8 & 11 & 5 & 8 \\
\hline Two children & 11 & 5 & 8 & 4 \\
\hline Three or more & 0 & 4 & 0 & 4 \\
\hline \multicolumn{5}{|l|}{ children } \\
\hline With one or & 6 & 16 & 8 & 13 \\
\hline \multicolumn{5}{|l|}{ more children } \\
\hline \multicolumn{5}{|l|}{ under 5} \\
\hline Total number of & 19 & 20 & 13 & 16 \\
\hline
\end{tabular}


${ }^{\mathrm{i}}$ This has, in part, been as a result of the work of feminist activists (Leathwood and Read, 2009).

ii The students were recruited through the following means: placing advertisements at key student locations, at university childcare facilities and on university intranet sites; asking members of staff to forward information about the project to any student-parents they knew; and snowballing from those who volunteered to take part.

iii The NUS report (2009) indicates that between five and eight per cent of undergraduate students and about a third of postgraduates are parents.

${ }^{\text {iv }}$ Pseudonyms are used throughout.

${ }^{\mathrm{v}}$ In general, the patterns described by the Newer University students were similar for single parents and those who were co-habiting. 